\title{
Introducing primary care research teaching in Ukraine: description and evaluation of the ' $\mathrm{ABC}$ ' research methods course
}

\author{
Authors: Michael Harris ${ }^{1,2}$, Andriy Kolesnyk ${ }^{3}$, Gordon Taylor ${ }^{4}$, Pavlo Kolesnyk ${ }^{3}$ \\ ${ }^{1}$ Shupyk National Academy of Postgraduate Education, Ukraine \\ ${ }^{2}$ Berner Institut für Hausarztmedizin (BIHAM), University of Bern, Switzerland \\ ${ }^{3}$ Medical Faculty, Uzhhorod National University, Ukraine \\ ${ }^{4}$ College of Medicine \& Health, University of Exeter, UK
}

\begin{abstract}
Ukraine has a developing and expanding system of general practice, but only a rudimentary academic primary care system and no research skills training for general practitioners (GPs). We designed and evaluated a transnational primary care research skills course for Ukrainian GPs.

The ABC course is series of three 2-day workshops, designed to teach the basics of primary care research to early-career Ukrainian GPs. It was delivered by Ukrainian and British experts, using innovative, interactive teaching methods. Evaluation measures included participants' assessment of their research abilities, and changes in their attitudes, intentions and actions regarding their research practice.
\end{abstract}

Seventeen Ukrainian GPs took part. There was a 1.32-point increase in research ability selfassessment 5-point Likert scores, with particular increases in literature review and budgeting 
abilities. Scores for research attitudes, intentions and actions increased by $4.0 \%$, though limited by a ceiling effect. Many participants subsequently developed their own research projects, and some set up primary care research skills courses in their own Ukrainian academic organisations.

The course resulted in increased levels of self-confidence and ability to plan primary care research, with improvements in participants' stages of change. It provides a model for providing and evaluating innovative educational interventions in post-soviet countries, giving them a basis for high-quality primary care research.

\section{Keywords}

Primary Health Care; Teaching Methods; Training; Evaluation; General Practitioners; International

\section{Word count}

2314 words. 


\section{Introduction}

Ukraine, a country with a population of 43 million inhabitants, gained independence from the Soviet Union in 1991. It has one of the lowest Gross Domestics Products (GDP PPP) per capita in Europe: \$9,233 in 2018, compared to the UKs'\$45,973 [1]. Ukraine has 19 medical schools producing over 10,000 graduates annually [2], and has 3.0 doctors per 1000 population [3]. Few healthcare reforms were initially made in the post-soviet period [4,5]. Family medicine struggled as a speciality, with a system in which informal patient payments to doctors were commonplace, and direct patient access to hospital specialists was the norm [6]. However, in recent years the system of primary medical care has been reorganised, with payment according to capitation, increased salaries for general practitioners (GPs) and an electronic management system [7,8]. In 2017, 15,020 of Ukraine's 18,6178 doctors were family doctors (8.1\%) [9], an increase from $1.9 \%$ in 2007 [5]. Family doctor training involves a two-year residency [10], with ten months of 'theoretical training' (lectures, seminars, case discussion) and a year's 'practical training' in family medicine clinics [11].

Ukrainian scientists' training does not involve undertaking original research or external peer review, and relatively poor foreign language skills alongside Ukraine's academic promotion system mean that few of its scientists publish in international peer-reviewed journals [12]. There has been a call for Ukraine's universities to adopt internationally recognised standards and support academics to reduce the 'brain drain' to other countries [12]. Ukraine has only two professors of family medicine [13], its family medicine postgraduate medical curriculum does not include research skills [10], and few dissertations by GPs are on family medicine topics. While there is a peer-reviewed family medicine journal, it is not included in internationally recognised scholarly databases.

As Ukraine had no primary care research skills courses, and therefore no way for the development of an evidence-base that was relevant to its GPs, we designed such a course for early-career Ukrainian GPs. Close cooperation between GP researchers in Ukraine and the United Kingdom 
(UK) allowed us to deliver a transnational course on primary care research skills in Ukraine, and evaluate its effect on participants' self-assessment of their research abilities, as well as on their attitudes, intentions and actions with respect to their research practice.

\section{Methods}

\section{Course design}

Three primary care research experts worked together over six months to develop the course. PK, a Ukrainian GP and academic, assessed the learning needs of potential participants, and $\mathrm{MH}$, a British GP with skills in primary care research and educational design, produced the educational model. PK, MH and GT, a British medical statistician and expert in research design, had regular videoconferences for detailed workshop planning. This resulted in a series of three 2-day residential workshops for early-career Ukrainian GP researchers, delivered in Ukraine, and designed to teach the basics of primary care research (Box 1).

\section{[Place Box 1 here]}

Over the three workshops, we covered the knowledge and skillsets that participants would need to be able to run their own primary research projects. The key subjects were covered in a series of presentations (Box 2), each of which was followed either by a demonstration or by a thirty-minute practical session in which pairs or trios of participants could put the principles into practice.

\section{[Place Box 2 here]}

We used a mixture of educational techniques, designed to make the workshops interactive and enjoyable. These teaching methods, while commonplace in Northern European medical education, were new to most of the participants (Box 3). 


\section{[Place Box 3 here]}

Time was allocated in the ' $A$ ' and 'B' workshops for trios of participants to choose and develop a research design task for them to work on over the next twelve months, and which they would need to present at the next workshop.

\section{Handling the language barrier}

While PK and some of the other Ukrainian participants could speak excellent English, some participants spoke little or no English, and neither MH nor GT could speak Ukrainian. MH and GT submitted their presentation slides before each workshop, then bilingual participants translated them into Ukrainian. During the lectures, MH and GT had their English versions on laptops in front of them, while the Ukrainian versions were projected onto the screen behind them. The translators acted as consecutive interpreters, translating sentence by sentence. This was effective and low cost but time-consuming, as the lecturers had to speak slowly enough for the translators to understand them, and then wait for the Ukrainian translation to be given. Participant questions and presentations followed a similar process in reverse.

Although the translation process slowed the teaching process down, we found that this usefully gave experts and participants time in which to reflect on what they had heard or were about to say. It was also helpful to participants, in that it forced the experts to use language that avoided unnecessary jargon and was simple enough for our non-professional interpreters to translate.

\section{Selecting participants}

Information about the course was sent to the heads of the 22 Ukrainian primary care university departments. Each department was invited to nominate one or two early-career GPs who had a particular interest in primary care research. 


\section{Evaluation methods}

In each workshop, we allocated time for participants to complete three evaluation forms:

- The Research Self-Efficacy Scale (RSES) questionnaire, to assess participants' selfassessment of their research abilities [14].

○ We compared participants' scores for the start and end of each workshop.

- A questionnaire to assess participants' attitudes, intentions and actions regarding primary care research [15], based on Prochaska's model of change [16].

- We compared the scores at the start of each workshop with the scores three months later.

- A traditional end-of-course feedback questionnaire.

- What did the participants think went well, and how could the workshops have been improved?

\section{Results}

Seventeen GPs took part in the course. All participants completed the evaluation forms as requested. While there were 'before and after' evaluations of each of the three workshops, here we evaluate the overall effect of the course by comparing the results of the questionnaires completed at the start of workshop 'A' with those following workshop ' $\mathrm{C}$ '.

\section{Changes in participants' self-assessment of their research abilities}

The RSES questionnaires assessed how well participants believed they were able to cope with research tasks, and whether attending the workshops changed those beliefs. For each of eleven skills, participants indicated their abilities on a 5-point Likert scale from 'Not at all able' to 'Very 
able', scored as 1 to 5 respectively. The mean scores before and after the series of workshops are given in Table 1.

\section{[Place Table 1 here]}

Overall, there was a 1.32-point increase in 5-point Likert scores of participants' own assessments of their research abilities. The RSES showed particular increases in participants' self-assessed literature review and budgeting abilities, as well as their skills in building a research team. Although key parts of the course were about identifying and writing research questions, and deciding on research strategies, there was relatively little increase in participants' scores for these.

\section{Progression in participants' 'stages of change'}

Participants completed 5-point Likert scales to show their level of agreement with each of 12 statements, from 'Strongly disagree' to 'Strongly agree', scored as 1-5. The mean scores before the course and three months after it are shown in Table 2.

\section{[Place Table 2 here]}

Participants' mean scores increased from 3.99 to 4.15 , an increase of $4.0 \%$. Their views on the need to learn about and do research increased over the course, and more of them indicated that they were working on research projects. The scores for some statements were already high before the $\mathrm{ABC}$ course, and for three of those reduced following the course.

\section{Traditional end-of-course feedback items}

As well as making a formal evaluation of the course, we adapted questions from the Berkeley course evaluations question bank [17] to ask participants about the quality of the course content, teaching and organisation, what the best things were, and how the course could have been improved. 
Participants wrote that they had decided to do the course because they lacked primary care research skills, and they wanted to get an international perspective on research. Many wanted to learn about medical statistics. The best things about the course were thought to be the interactive and innovative teaching methods, the ability for participants to express their own feelings and ideas, and the teaching on statistics and qualitative research. Possibilities for improvement included having more teaching on statistics and literature review skills. Some commented that, as a result of the course, they realised that family medicine research in Ukraine tended to be too complex. They thought that the course's international perspective was valuable, and they became aware of the mistakes in their own previous research work.

\section{ABC course scientific outcomes}

Four groups of participants were prompted to start new primary care research projects during the course, and presented them during the final session:

- How common is burnout among family doctors in Dnepropetrovsk?

- What is the perception of Family Medicine as a future career among Ukrainian and foreign medical students at Uzhgorod University?

- How feasible is it to make a cultural validation of a translated 'gut feelings questionnaire'?

- What is the role of the internet in patients' decision-making with relation to leading a healthy lifestyle?

Of the twelve participants who completed a survey nine months after the end of the course:

- eleven had developed new research questions;

- eleven had completed at least one primary care research project as a result of the $\mathrm{ABC}$ course, and nine were still working on projects;

- four had designed their own courses in primary care research methodology; 
- three of these had already had their new courses included in their institutes' or universities' mandatory training programmes;

- over 110 postgraduates had already completed these new courses.

An unexpected, but welcome, outcome of the ABC course was that all participants who completed the nine-month survey stated that they had been inspired by the course's interactive teaching methods and tried to emulate it in their own teaching practices.

\section{Discussion}

\section{Summary of findings}

The ABC course used innovative, interactive teaching methods to help early-career Ukrainian GPs to learn about and develop their primary care research skills. During the course they worked on their own research projects and then presented them. Their levels of self-confidence and their ability to plan primary care research increased. There were positive changes in most of their attitudes. Nine months later, almost all those surveyed had completed at least one primary care research project as a result of the $\mathrm{ABC}$ course, and four participants had gone on to develop primary care research courses for their own Ukrainian academic organisations.

\section{Strengths and limitations}

Three different evaluation methods were used, and all participants completed all the evaluation forms. ABC course members came from eight regions of Ukraine. The evaluation outcome measures were decided in advance and used tools that have previously been used in similar contexts. The cohort size was small, and it is likely that the course members were particularly enthusiastic and receptive to the ideas that were discussed; this may restrict the generalisability of our findings. We measured self-perceived improvement in research abilities and readiness to 
change, but we used no objective measures of research skills or increase in research work. It may be that participants gave socially desirable answers to the evaluation questions.

\section{Comparison with existing literature}

A UK-academic-supported research skills course was delivered in Ghana, another country that did not already have such a course [18]. Its two 1-week workshops, which were facilitated by UK and Ghanaian tutors, used group work, short talks, demonstrations, and self-directed learning. The RSES, with a 10-point Likert scale, was administered at the end of the course, giving a mean score was 8.43 out of 10. This is similar to the ABC participants' post-course RSES score of 4.27 out of 5.

The Ghanaian research skills course showed an increase participants' positive responses to statements about research-related attitudes, intentions and actions. While the ABC course's increase in these scores was modest, with reductions in some scores, this may be due to a 'ceiling effect' as the initial scores for those statements were already high.

A Canadian group used a stages of change model to evaluate a research transfer training programme for members of a psychiatry department and a research institute [15]. The course design used adult learning principles in three 2-hour small-group sessions. Scores for intention to change increased, but differences in measurement methods make direct comparisons with the ABC course difficult.

An evaluation of a research skills course in Finland, which had modules every three weeks for a year, found that participants gave highest scores for working on their own research plans and learning about research design [19]. This contrasts with our course participants who particularly valued the teaching methods and interactive approach, perhaps because it was the first time that some of them had experienced these methods. 


\section{Implications and conclusions}

Many Eastern European countries provide little or no training on primary care research methodology. This can result in poor quality research work and lack of peer-reviewed publications. However, following this successful evaluation, and with the support of the European GP Research Network (EGPRN), we plan to start ABC courses in Hungary and the Czech Republic in the next year.

We found that most of our course participants have been able to translate their coursework into reallife research work without ongoing support from the $\mathrm{ABC}$ course experts, and some have subsequently designed and produced their own primary care research skills courses. Further followup is needed to assess the quality of this work. While in the seven years following the Finnish research skills course 28 of the 46 participants (61\%) had published PubMed-indexed papers [19], it remains to be seen whether this is achievable in a country that has a rudimentary academic primary care system.

The $\mathrm{ABC}$ course provides a model for providing and evaluating innovative educational interventions in post-soviet countries, which will provide the basis for high-quality primary care research in these countries.

\section{Biographical note}

Michael Harris is a GP in the UK and Visiting Professor at Shupyk National Academy of Postgraduate Education, Ukraine.

Andrew Kolesnyk is a final year medical student at Uzhgorod National University, Ukraine.

Gordon Taylor is Professor of Medical Statistics at the University of Exeter, UK. 
Pavlo Kolesnyk is a GP Trainer and Associate Professor at Uzhgorod National University Ukraine.

\section{Acknowledgments}

We are grateful to the Ukrainian Association of Family Medicine for its help in organising the workshops and to the EGPRN for its support. We would also like to give our thanks to the GPs who participated in the ABC course and its evaluation.

\section{Disclosure statement}

The authors report no conflicts of interest.

\section{Ethical considerations}

As this was an evaluation of a training programme, ethical approval was not required.

\section{Funding}

The research received no external funding.

\section{References}

[1] International Monetary Fund. List of sovereign states in Europe by GDP (PPP) per capita [Internet]. Int. Monet. Fund. [cited 2020 Mar 30]. Available from: https://data.worldbank.org/indicator/NY.GDP.PCAP.PP.CD.

[2] Ministry of Health of Ukraine. Стратегія розвитку медичної освіти в Україні. [Strategy of development of medical education in Ukraine]. [Internet]. Ministry of Health of Ukraine; 2018 [cited 2020 Apr 20]. Available from: https://moz.gov.ua/uploads/1/8475-medical_education_analytics.pdf.

[3] The World Bank. Physicians (per 1,000 people) [Internet]. World Bank. [cited 2020 Mar 30]. Available from: https://data.worldbank.org/indicator/sh.med.phys.zs.

[4] Romaniuk P, Semigina T. Ukrainian health care system and its chances for successful transition from Soviet legacies. Glob. Health. 2018;14:116. 
[5] Lekhan V, Rudiy V. Key strategies for further development of the health care sector in Ukraine. Joint report. [Internet]. Kiev, Ukraine; 2007 [cited 2020 Apr 21]. Available from: http://siteresources.worldbank.org/INTUKRAINE/147271-

1140529183591/21312776/KeystrategiesforfurtherdevelopmentofthehealthcareEng.p df.

[6] Kolesnyk P, Švab I. Development of family medicine in Ukraine. Eur. J. Gen. Pract. 2013;19:261-265.

[7] Про державні фінансові гарантії медичного обслуговування населення [On state financial guarantees of medical services for the population] [Internet]. 2020. Available from: https://zakon.rada.gov.ua/go/2168-19.

[8] Про затвердження Порядку надання первинної медичної допомоги [On approval of the procedure for primary care] [Internet]. 2018. Available from:

https://zakon.rada.gov.ua/go/z0348-18.

[9] State Statistics Committee of Ukraine. Заклади охорони здоров'я та захворюваність населення України у 2017 році. [Health facilities and morbidity of the Ukrainian population in 2017: statistical bulletin] [Internet]. 2018 [cited 2020 Apr 10]. Available from: https://zakon.rada.gov.ua/laws/show/z0348-18.

[10] Про затвердження Положення про спеціалізацію (інтернатуру) випускників вищих медичних і фармацевтичних закладів освіти III-IV рівня акредитації медичних факультетів університетів [On approval of the regulation on specialization (internship) of graduates of higher medical and pharmaceutical higher educational establishments of Ukraine] [Internet]. 19.09.1996 N 291 1996. Available from: https://zakon.rada.gov.ua/go/z0696-96.

[11] Про затвердження Переліку спеціальностей та строки навчання в інтернатурі випускників медичних і фармацевтичних вищих навчальних закладів [On approval of the list of specialties and terms of study in the internship of graduates of medical and pharmaceutical higher education institutions] [Internet]. 6.03 .96 p. N 50 1996. Available from: https://zakon.rada.gov.ua/go/z0134-96.

[12] Gorobets A. Modernize Ukraine’s university system. Nature. 2011;473:154-154.

[13] Open Science in Ukraine. Нові вимоги до фахових видань [New requirements for professional editions] [Internet]. [cited 2020 Apr 20]. Available from: https://openscience.in.ua/vak-project-12-17.html.

[14] Unrau YA, Beck AR. Increasing Research Self-Efficacy Among Students in Professional Academic Programs. Innov. High. Educ. 2004;28:187-204.

[15] Buckley LL, Goering P, Parikh SV, et al. Applying a "stages of change" model to enhance a traditional evaluation of a research transfer course. J. Eval. Clin. Pract. 2003;9:385-390.

[16] Prochaska J, DiClemente C. Transtheoretical therapy: toward a more integrative model of change. Psychother Theory Res Pr. 1982;19:276-288.

[17] Centre for teaching and Learning. Course Evaluations Question Bank. 2017; Available from: https://teaching.berkeley.edu/course-evaluations-question-bank. 
[18] Bates I, Ansong D, Bedu-Addo G, et al. Evaluation of a learner-designed course for teaching health research skills in Ghana. BMC Med. Educ. 2007;7:18.

[19] Liira H, Koskela T, Thulesius $\mathrm{H}$, et al. Encouraging primary care research: evaluation of a one-year, doctoral clinical epidemiology research course. Scand. J. Prim. Health Care. 2016;34:89-96.

[20] Pendleton D, Tate P, Havelock P. The Consultation: An Approach to Learning and Teaching. Oxford, UK: Oxford University Press; 1984. 
Box 1. The ABC course workshops.

- Workshop 'A': ‘Approaches to family medicine research' - the different types of research methodology and how to critically appraise research papers; October 2017.

- Workshop 'B': 'Building your research project' - the skills needed to plan simple research projects; October 2018.

- Workshop 'C': 'Communicating your research project to others' - participants presented the results of their projects, received feedback on their presenting skills, and had advice on writing for publication; October 2019. 
Box 2. The ABC course lectures.

- Designing a research question.

- Understanding and doing qualitative research.

- Choosing the right quantitative study design.

- How to understand and analyse randomised controlled trials.

- How to understand and analyse cohort \& case-control research.

- How to understand and analyse research on diagnostic tests.

- Statistics which describe data.

- Statistics which test differences and which compare risk;

- How to write a research proposal.

- How to present a paper at a conference.

- Writing for publication. 
Box 3. Educational methods used in each workshop.

- 'Warmup games' to start each session.

- Asking participants 'What do you want to get out of the workshop?'

- Asking participants 'What have you learnt today?'

- Ensuring that each participant gave a short presentation.

- Using Pendleton's feedback rules [20]: after each participant presentation, everyone (starting with the presenter) said what went well, then what could be improved.

- Working in pairs and trios, then feeding back to the large group.

- Practical sessions on qualitative coding and thematic analysis.

- Demonstrations of statistical analysis of data provided by participants.

- 'Elevator pitch' sessions: participants' two-minute presentations of research ideas.

- No session lasting longer than 90 minutes without a coffee or lunch break. 
Table 1. Comparison of pre- and post-ABC scores for participants' self-assessment of their research abilities, ordered by increase in score.

\begin{tabular}{|c|c|c|c|}
\hline I am able to... & $\begin{array}{l}\text { Before 'A' } \\
\text { workshop }\end{array}$ & $\begin{array}{l}\text { After 'C' } \\
\text { workshop }\end{array}$ & $\begin{array}{l}\text { Change } \\
\text { in score }\end{array}$ \\
\hline ... write a balanced and comprehensive literature review. & 2.3 & 4.1 & 1.8 \\
\hline ... produce a realistic budget for my research project. & 2.5 & 4.3 & 1.8 \\
\hline $\begin{array}{l}\ldots \text { do an effective electronic database search of the } \\
\text { literature. }\end{array}$ & 2.5 & 4.1 & 1.6 \\
\hline ... put together a team to help me to conduct my research. & 2.7 & 4.2 & 1.5 \\
\hline $\begin{array}{l}\text {... design and implement the best strategy for collecting } \\
\text { my data. }\end{array}$ & 2.4 & 3.8 & 1.4 \\
\hline $\begin{array}{l}\text {... choose a research design that will answer my research } \\
\text { question or hypothesis. }\end{array}$ & 3.1 & 4.5 & 1.4 \\
\hline ... effectively present my study and its implications. & 3.5 & 4.9 & 1.4 \\
\hline $\begin{array}{l}\text {... teach someone else how to design and implement a } \\
\text { simple research project. }\end{array}$ & 3.3 & 4.3 & 1.0 \\
\hline $\begin{array}{l}\text {... design and implement the best data analysis strategy for } \\
\text { my research study. }\end{array}$ & 3.3 & 4.2 & 0.9 \\
\hline $\begin{array}{l}\ldots \text { formulate a clear research question or testable } \\
\text { hypothesis to address a clinical problem. }\end{array}$ & 3.3 & 4.2 & 0.9 \\
\hline ... identify a clinical problem that is amenable to research. & 3.5 & 4.3 & 0.8 \\
\hline Mean scores & 2.95 & 4.27 & 1.32 \\
\hline
\end{tabular}


Table 2. Comparison of pre- and post-ABC scores for progression in participants' 'stages of change', ordered by increase in score.

\begin{tabular}{|c|c|c|c|}
\hline & $\begin{array}{l}\text { Before A } \\
\text { workshop }\end{array}$ & $\begin{array}{c}\text { After C } \\
\text { workshop }\end{array}$ & $\begin{array}{l}\text { Change } \\
\text { in score }\end{array}$ \\
\hline I am working on a research project. & 4.1 & 4.7 & 0.6 \\
\hline I should do more research myself. & 4.0 & 4.5 & 0.5 \\
\hline Learning research skills is important. & 4.6 & 5.0 & 0.4 \\
\hline $\begin{array}{l}\text { I have spoken at a meeting about increasing the amount } \\
\text { of research that we do. }\end{array}$ & 2.7 & 3.1 & 0.4 \\
\hline $\begin{array}{l}\text { I will suggest including research into our work with } \\
\text { colleagues. }\end{array}$ & 3.9 & 4.2 & 0.3 \\
\hline $\begin{array}{l}\text { I have changed my clinical practice as a result of doing } \\
\text { research. }\end{array}$ & 3.7 & 4.0 & 0.3 \\
\hline $\begin{array}{l}\text { I plan to include research findings in my clinical } \\
\text { practice. }\end{array}$ & 4.2 & 4.4 & 0.2 \\
\hline Understanding how to do research is relevant me. & 4.7 & 4.9 & 0.2 \\
\hline $\begin{array}{l}\text { I have suggested to some of my colleagues that they } \\
\text { should do research. }\end{array}$ & 3.5 & 3.6 & 0.1 \\
\hline $\begin{array}{l}\text { I have spoken at a meeting or to a colleague about } \\
\text { increasing the use of research in our work. }\end{array}$ & 2.9 & 3.0 & 0.1 \\
\hline $\begin{array}{l}\text { I should include research findings into my clinical } \\
\text { practice. }\end{array}$ & 4.3 & 4.2 & -0.1 \\
\hline I plan to learn more about how to do research. & 4.9 & 4.5 & -0.4 \\
\hline $\begin{array}{l}\text { I will suggest that we discuss how to use research } \\
\text { results at our local meetings. }\end{array}$ & 4.4 & 3.9 & -0.5 \\
\hline
\end{tabular}


